WIDER Working Paper 2016/60

Caste differences in behaviour and personality

Evidence from India

Utteeyo Dasgupta, ${ }^{1}$ Subha Mani, ${ }^{2}$ Smriti Sharma, ${ }^{3}$ Saurabh Singhal ${ }^{3}$

May 2016 
Abstract: The persistent gap in economic outcomes between the upper and lower caste groups in India is typically explained through differences in endowments and the presence of discrimination. While there is sizable literature that examines caste gaps in physical and intellectual human capital, this paper contributes to a small literature that evaluates caste differentials in behavioural preferences and personality traits that are possibly associated with the persistent economic gap between these castes. Using data from experiments and surveys conducted among a large sample of Indian undergraduate students, we find significant caste differences in behaviour and personality such that Scheduled Castes, Scheduled Tribes, and Other Backward Classes are less likely to be endowed with the behavioural preferences and personality traits that tend to affect educational attainment, labour market performance, and overall wellbeing positively. Our results have implications for revising the focus of current castebased policy formulations.

Keywords: behaviour, personality, caste, artefactual field experiments, India JEL classification: I23, C9, C18, J24, O15

Tables: at the end of the paper.

Acknowledgements: The authors would like to thank UNU-WIDER and International Growth Center-India Central for support. We thank Ashwini Deshpande and participants at the UNU-WIDER workshop on 'Discrimination and Affirmative Action: What have we learnt so far?' for comments. Neha Agarwal, Riju Bafna, Piyush Bhadani, Japneet Kaur, and Anshul Yadav provided excellent research assistance. We are grateful to the staff at the various colleges in the University of Delhi for lending their support in conducting the study. The usual disclaimer applies.

\footnotetext{
${ }^{1}$ Department of Economics, Wagner College, NY, and Center for International Policy Studies, Fordham University, NY, US; 2 Department of Economics and Center for International Policy Studies, Fordham University, NY, US, Population Studies Center, University of Pennsylvania, PA, US, and IZA, Bonn, Germany; ${ }^{3}$ UNU-WIDER, Helsinki, Finland; corresponding author: smriti@wider.unu.edu.
}

This study has been prepared within the UNU-WIDER project on 'Discrimination and Affirmative Action: What have we learnt so far?', which is part of a larger research project on 'Disadvantaged Groups and Social Mobility'.

Copyright (C) UNU-WIDER 2016

Information and requests: publications@wider.unu.edu

ISSN 1798-7237 ISBN 978-92-9256-103-1

Typescript prepared by Leslie O’Brien.

The United Nations University World Institute for Development Economics Research provides economic analysis and policy advice with the aim of promoting sustainable and equitable development. The Institute began operations in 1985 in Helsinki, Finland, as the first research and training centre of the United Nations University. Today it is a unique blend of think tank, research institute, and UN agency—providing a range of services from policy advice to governments as well as freely available original research.

The Institute is funded through income from an endowment fund with additional contributions to its work programme from Denmark, Finland, Sweden, and the United Kingdom.

Katajanokanlaituri 6 B, 00160 Helsinki, Finland

The views expressed in this paper are those of the author(s), and do not necessarily reflect the views of the Institute or the United Nations University, nor the programme/project donors. 
The caste system is a deeply entrenched cultural institution that has festered to create and reinforce social as well as economic inequalities in India. ${ }^{1}$ It is a critical determinant of power and poverty in contemporary India. A number of studies have shown that the lower castes-former untouchables (Scheduled Castes, SCs hereafter) - and indigenous tribes (Scheduled Tribes, STs hereafter) have on average fared worse than the upper castes. They have fallen behind in educational and occupational outcomes (Munshi and Rosenzweig 2006), wage earnings and consumption expenditures (Kijima 2006; Hnatkovska, Lahiri, and Paul 2012), and ownership and performance of small businesses (Deshpande and Sharma 2013, 2016). They are also likely to be at the receiving end of crimes because of their social identity (Sharma 2015). Further, even successful low caste individuals may not be viewed on the basis of their own merits but rather through the lens of their collective stigmatized caste identity (Jaspal 2011). A third category known as the Other Backward Classes (OBCs hereafter), although not stigmatized as the SCs and STs, have suffered from limited opportunities and poor socioeconomic outcomes, similar to the SCs and STs.

Given the strong positive association between human capital accumulation and long-term welfare outcomes (Orazem and King 2008), it is then not surprising that lower stocks of observable/measurable human capital endowments among these marginalized groups perpetuate poor economic outcomes. In comparison to their upper caste counterparts, low caste individuals also earn lower returns on the same level of endowments due to the pervasive presence of social and economic discrimination practiced overtly and in subtle ways (e.g., Siddique 2011; Hanna and Linden 2012; Kumar 2013). ${ }^{2}$ The gaps in performance between groups could be exacerbated because of self-fulfilling prophecies: prevalence of negative stereotypes about marginalized groups and their expectation of differential treatment and discrimination would reduce their incentive for undertaking productivity-enhancing investments (Coate and Loury 1993).

In this paper, our objective is to examine caste-based differences in behavioural preferences such as risk, competitiveness, confidence, and egalitarianism, and in personality traits as measured by Big Five, locus of control, and grit. Understanding caste-based gaps in behavioural preferences and personality traits, which are typically unobserved/unmeasured in large-scale datasets, is crucial, as they are important predictors of educational attainment, occupational choice, labour market performance, and overall well-being (Borghans, Duckworth, Heckman, and ter Weel 2008; Buser, Niederle, and Oosterbeek 2014; World Development Report 2015). Given the observed gaps in economic well-being, one would expect some differences across castes in behaviour and personality. Additionally, these gaps could also arise due to internalization of negative stereotypes by the low castes. For instance, Hoff and Stiglitz (2010) show that belief systems may perpetuate gaps between majority and minority groups by shaping perceptions of inferiority among the latter, thereby resulting in an equilibrium where such beliefs are confirmed.

\footnotetext{
1 The caste system is a social stratification system that places individuals into hereditary, largely endogamous, and occupation-specific groups. On the lowest rung are the 'Ati-Shudras' ('untouchables') with whom any contact was seen as polluting. They were forced to live in segregated housing; denied access to schools, and places of worship attended by upper castes; and required to maintain physical distance from upper castes in order not to pollute them. Also, there are the indigenous tribes (Adivasis) who on account of geographical isolation have been socially distanced and face large-scale exclusion. Both these groups have been beneficiaries of affirmative action since 1950 in the form of reservations in national and state legislatures, local governments, institutions of higher education, and government jobs.

${ }^{2}$ For detailed discussions on economic discrimination in India, see Deshpande (2011). For a recent review article on field experiments detecting discrimination, see Bertrand and Duflo (2016).
} 
Our question is nested in the broader literature on social identity and preferences (Akerlof and Kranton 2010). Steele and Aronson (1995) show in a range of studies that racial stereotypes about intellectual ability impair test performance among African-Americans, even in cases where tests do not diagnose ability. Benjamin, Choi, and Strickland (2010) find that making AsianAmerican and native black subjects' ethnicity salient causes them to become more patient. In the Indian context, Bros (2014) using the World Values Survey finds that caste is a major determinant of perceived social rank, such that even after controlling for income, education, and occupation, SC and ST respondents are more likely to believe that they belong to lower social ranks as compared to their upper caste counterparts. She attributes this result to an internalized diminished self-image based on repeated experiences of discrimination and the continued expectation of discrimination. ${ }^{3}$ Spears (2016) finds that SCSTs and OBCs in rural north India report lower life satisfaction compared to the upper castes, and the difference cannot be fully explained by caste differences in wealth and education, even after controlling for village fixed effects. Hoff and Pandey (2006) examine whether publicly revealing subjects' caste affiliation in Indian villages affects their performance on a cognitive task. They find that when caste identities are anonymous, low caste and high caste students have similar performance and are equally likely to choose a tournament compensation scheme. However, when caste is made known publicly, there is a significant drop in the performance of low castes and their willingness to compete. They attribute this to 'stereotype threat', which postulates that stereotypes associated with a group affect individual performance when group identity is made salient. Mukherjee (2015) primes subjects about their caste and gender identities to find girls' aspirations to be biased downwards when gender is made salient and upper caste parents' aspirations for their children's future to be higher when caste is made salient.

In this paper, we contribute to a small but growing literature examining caste differences in behaviour and personality by combining survey responses along with observed choices from artefactual field experiments among a large sample of college students at the University of Delhi in India. Our results indicate that low caste (SCSTs and OBCs) subjects are relatively less competitive, less confident, and more egalitarian. Additionally, low caste subjects in our student sample were found to be less gritty, and scored more poorly on measures of locus of control, conscientiousness, and extraversion.

We also contribute to the literature that underscores the importance of early-life circumstances and socioeconomic environment in developing one's personality and preferences (e.g., Almas, Cappelen, Salvanes, Sorensen, and Tungodden 2015; Deckers, Falk, Kosse, and SchildbergHörisch 2015). Children from minority groups are deprived not only based on their low socioeconomic status but also because they tend to grow up in environments that are typically characterized by low levels of human capital and lack role models that can play a decisive role in shaping their character and aspirations. Our sample of students provides sufficient heterogeneity in terms of family background thereby allowing us to explore whether high socioeconomic status alleviates some of the pure caste disadvantage. Our results indicate that higher socioeconomic status and attendance at a private school have compensatory effects on certain personality traits for SCSTs and OBCs. From a policy perspective, our results call for redesigning the current structure of affirmative action policies in India to allow for targeted interventions to start at an early age to mitigate the subsequent accumulation of disadvantage into adulthood.

\footnotetext{
3 Deshpande and Newman (2007) find low caste university students to have lower occupational and wage expectations than their upper caste counterparts do.
} 
This paper is organized as follows: Section 2 elaborates on the experiment design and Section 3 lays out the estimation framework. Summary statistics, regression results, and robustness checks are presented in Section 4. Concluding remarks follow in Section 5.

\section{Experiment design}

We conducted artefactual field experiments and administered a detailed socioeconomic survey to students enrolled in undergraduate programmes at the University of Delhi (DU) in 2014. ${ }^{4} \mathrm{It}$ should be noted that unlike other studies that make identities salient, we do not do so.

The experiment consisted of a series of incentivized tasks. First, subjects' preferences for competitiveness and confidence were elicited using a competition task adapted from Niederle and Vesterlund (2007). Subjects participated in a real effort task that involved adding up four two-digit numbers where they were asked to predict their performances after a practice round, and choose between a piece-rate and tournament compensation scheme. The piece-rate scheme paid Rs. 10 for every correctly solved problem; the tournament scheme paid double that amount for every correct answer if the subject out-performed a randomly selected DU student who had solved the questions earlier. ${ }^{5}$ We define competitiveness as a dummy that takes a value 1 if the subject chose the tournament compensation scheme and 0 if the subject chose the piece-rate compensation scheme. We define confidence as a dummy that takes a value 1 if the subject believed that her performance in the actual task would exceed those of others in the university, 0 otherwise.

Second, distributional preferences were measured using the Bartling, Fehr, Maréchal, and Schunk (2009) framework that asks subjects to state their preferences over a series of four binary distributional choices that would affect their and an anonymous participant's earnings. In all four choices, option $\mathrm{A}$ is an equal distribution and option B is an unequal distribution. In row 1, a subject chooses between an allocation (Rs. 200, Rs. 200) and (Rs. 200, Rs. 120), and choosing the equal option is consistent with prosocial behaviour since the subject can increase her partner's payoff in a costless manner. In row 2, choosing (Rs. 200, Rs. 200) over (Rs. 320, Rs. 80) indicates costly prosocial behaviour on the part of the subject since she incurs a pecuniary cost on herself. In row 3, choosing (Rs. 200, Rs. 200) over (Rs. 200, Rs. 360) reflects envious behaviour by the subject. Finally, in row 4 choosing (Rs. 200, Rs. 200) over (Rs. 220, Rs. 360) indicates the subject's willingness to incur pecuniary costs to ensure that her outcome is not relatively unfavourable and indicates costly envy. To rule out any order effects, we randomized the sequence in which these distributional choices were presented across sessions. We define egalitarianism as a dummy that takes a value 1 if the subject chooses the equal division (option A) in each row, 0 otherwise. We further define subjects as being aheadness averse (or averse to advantageous inequality) if they always choose the equal distribution in cases where they can have the more favourable outcome in the unequal distribution. Conversely, a subject is bebindness averse (or averse to disadvantageous inequality) if she always chooses the equal distribution in scenarios where she has the unfavourable outcome in the unequal distribution.

Third, we used the investment game of Gneezy and Potters (1997) to elicit risk attitudes. Subjects had to invest a portion of their endowment of Rs. 150 in a risky lottery (with equal chance of win or loss) and set aside the remainder. If the investment was successful (based on a

\footnotetext{
4 The experimental instructions and the survey instruments are available from the authors upon request.

${ }^{5}$ We implemented a pilot version of this game where 40 students from DU had participated in this game. We use the performance of these students for comparison in the tournament wage scheme.
} 
roll of a dice), subjects received triple the invested amount in addition to any amount they set aside. If they lost the lottery, they only received the amount that was set aside. We define risk attitude as the proportion allocated to the risky lottery in the investment game where higher invested amounts indicate lower risk aversion.

Fourth, as a part of the socioeconomic survey, we administered standard inventories to measure Big-Five personality traits, locus of control, and grit. The Big-Five personality traits were measured using the 10-item inventory (Gosling, Rentfrow, and Swann Jr. 2003), where each item has a score between 1 (disagree strongly) and 7 (agree strongly). The Big-Five personality traits are defined as follows:

Openness to experience is the tendency to be open to new aesthetic, cultural, or intellectual experiences; Conscientiousness refers to a tendency to be organized, responsible, and hardworking; Extraversion relates to an outward orientation rather than being reserved; Agreeableness is related to the tendency to act in a cooperative and unselfish manner; and Neuroticism (opposite of Emotional stability) is the tendency to experience unpleasant emotions easily, such as anger, anxiety, depression, or vulnerability. Additionally, we implemented the 8-item Grit scale of Duckworth and Quinn (2009) where a higher score on the grit scale implies greater ability to pursue long-term goals with sustained effort. Finally, locus of control was measured using 13 items from Rotter (1966). Subjects with a high score exhibit more internal locus of control indicating that they believe that events in life are more under their control as compared to those with an external locus of control. We standardize all personality traits using the sample mean and standard deviation and use z-score constructs of these variables in the regression analysis. We also collected details on family background characteristics including caste, academic performance, and participation in extracurricular activities in the socioeconomic survey.

Overall, we conducted 60 sessions with 2,065 subjects, resulting in approximately 34 subjects per session. Each session lasted about 75 minutes. All subjects received a show-up fee of Rs. 150. The average additional payment was Rs. $230 .{ }^{6}$ All subjects participated only once in the study.

\section{Estimation strategy}

The literature examining the determinants of multiple behavioural preferences, personality traits, and aspirations either treats each of the measures as an independently determined outcome or uses an index constructed using factor analysis. However, as the same subject makes choices in the risk game, competition game, and distribution game, we estimate these equations using a framework that allows for these choices to be correlated. We report the correlation between the error terms obtained from estimating each of the behavioural preferences and personality traits separately using OLS (see Appendix Tables A1-A2). We are able to reject the null ( $\mathrm{p}$-value = $0.00)$ that the outcomes are independent for the vector of elicited behavioural preferences and personality traits. This supports our choice of estimating the following Seemingly Unrelated Regression (SUR) model that allows the errors to be correlated across equations, thereby improving upon the precision of the estimates, and also reducing type II errors, i.e., the risk of attaining low statistical power.

$$
\mathrm{Y}_{\mathrm{ij}}=\beta_{0}+\beta_{1} \mathrm{SCST}_{\mathrm{i}}+\beta_{2} \mathrm{OBC}_{\mathrm{i}}+\sum_{\mathrm{k}=1}^{\mathrm{N}} \sum_{\mathrm{j}=1}^{\mathrm{M}} \delta_{\mathrm{jk}} \mathrm{Z}_{\mathrm{ijk}}+\sum_{\mathrm{k}=3}^{\mathrm{N}} \beta_{\mathrm{k}} \mathrm{X}_{\mathrm{ik}}+\varepsilon_{\mathrm{s}}+\varepsilon_{\mathrm{ij}}
$$

\footnotetext{
${ }^{6}$ At the time of conducting the study, the exchange rate was US $\$ 1=$ Rs. 60 .
} 
$\mathrm{Y}_{\mathrm{ij}}$ is the dependent variable (behavioural preferences and personality traits) observed for individual $i$ and outcome $j$, SCST is a dummy that takes a value 1 if the subject belongs to the Scheduled Caste or Scheduled Tribe group, 0 otherwise. OBC is a dummy that takes a value 1 if the subject belongs to the Other Backward Classes, 0 otherwise. $\mathrm{Z}$ is a vector of controls that varies by outcome, $j$, in line with the previous literature. Note that while risk preferences and confidence are used as outcome variables, we use alternative measures of these variables as controls (in vector $Z$ ) in the regression where competitiveness is the outcome. Since the RHS controls for risk and confidence are different from the outcome variables used to measure risk and confidence, under the assumption of no correlated measurement error, we can still obtain unbiased estimates of risk preference and confidence from our SUR results. X is a vector of family background characteristics and demographic characteristics that are included in all specifications and does not vary by the outcome variable, such as male (takes a value 1 if male, 0 if female), Hindu (takes value 1 if belonging to Hindu religion, 0 otherwise), age (in years), number of siblings, private school (takes a value 1 if the individual was enrolled in a private school, 0 otherwise), employed mother (takes a value 1 if mother is working, 0 otherwise), high socioeconomic status (takes a value 1 if both parents have graduate or postgraduate degree or if monthly family income exceeds Rs. 50,000, 0 otherwise). We control for session level unobservables $\left(\varepsilon_{s}\right)$ using session fixed-effects. $\varepsilon_{i}$ is the iid error term.

\section{$4 \quad$ Results}

\subsection{Summary statistics}

Table 1 presents the mean and standard deviation for each of our outcome variables and control variables, for the pooled sample, and also stratified by caste. In the last three columns, we report the p-values obtained from two-sided t-tests comparing upper castes to OBCs, upper castes to SCSTs, and OBCs to SCSTs respectively.

In Table 1, Panel A summarizes the behavioural preferences. In our sample, 31 per cent of the subjects chose the competitive remuneration by deciding to enter the tournament, and we observed no caste differences in willingness to compete. About one-third of our sample is confident, in that they expect themselves to perform better than other students in DU. OBCs are significantly more confident than the upper castes and SCSTs. Subjects on average invest about 47 per cent of their endowment in the risky asset; among the different caste groups, upper castes invest the smallest proportion of their endowment in the risky asset. Subjects' preferences for equality also differ significantly by caste: lowest among upper caste (13 per cent) and almost similar among SCSTs (18 per cent) and OBCs (19 per cent).

Subjects' Big Five personality traits, locus of control, and grit are summarized in Panel B. In general, we observe some caste differences in all personality traits except emotional stability. Upper caste subjects score higher on scales of extroversion, agreeableness, openness to experience, and grit relative to OBCs and SCSTs. Both upper caste and OBC students exhibit similar levels of conscientiousness but higher than SCSTs. While OBCs score significantly higher than upper castes in the locus of control scale, there is no caste difference between upper caste and SCST subjects. OBCs score significantly higher than SCSTs in terms of agreeableness, conscientiousness, and locus of control but for other personality traits, the SCST-OBC gap is not significant.

Average family background characteristics of our sample are reported in Panel C. There is an equal distribution of males and females, the average subject has one sibling, and 90 per cent of our subjects are Hindus. Approximately 70 per cent of subjects graduated from a private high 
school, and 71 per cent of the sample belongs to families with a high socioeconomic status (SES). Finally, only one-fourth of the mothers of our subjects were employed at the time of the survey. As expected and in line with the literature, we find significant caste-based differences in the family background characteristics reported in Panel C. Upper caste subjects are significantly more likely than OBCs and SCSTs to have attended a private school, have fewer siblings, have a mother who is employed, and belong to high SES families. We find that the OBCs perform significantly better than SCST in terms of features like SES, number of siblings, mother's employment, and private school attendance. This is in line with existing evidence that finds that the socioeconomic characteristics of OBCs lie somewhere in between those of upper castes and OBCs (Deshpande and Ramachandran 2013).

In Panel D of Table 1, we summarize the variables used as controls in only certain specifications. As expected, we find a significant caste gap in cognitive ability (measured using the Raven's test), and performance in practice and actual number-addition tasks in the competition game. Interestingly, we also find that OBCs and SCSTs are significantly more aheadness averse than the upper castes but there are no caste differences in behindness aversion.

\subsection{Regression results}

Table 2 presents the determinants of behavioural preferences using the SUR framework. Our main coefficients of interest in these regressions are the caste dummies: OBC and SCST, with upper caste serving as the reference group. SCSTs and OBCs are 6.5 percentage points and 7.5 percentage points less likely respectively to compete than the upper castes. The SCSTs are also eight percentage points less likely to be confident. We do not find a significant difference between the confidence levels of the OBCs and upper castes however. Risk preferences for the SCSTs and OBCs remain comparable to those of the upper castes with no significant difference across caste groups. While SCSTs differ significantly from OBCs in confidence, there are no OBC-SCST differences in terms of competitiveness or risk preferences (see bottom panel of Table 2).

Interestingly, SCSTs and OBCs are 5-6 percentage points more likely to prefer an equitable distribution compared to the upper castes, with no caste difference between SCSTs and OBCs. This is in line with the finding in Alesina and Giuliano (2011) who find blacks to be more supportive of redistributive policies as compared to whites in the USA. There are two possible explanations for our findings. First, SCSTs and OBCs in our sample, and in general, belong to the lower socioeconomic strata of society, which could lead them to have stronger preferences for income redistribution. Second, since the low caste groups have been beneficiaries of various welfare and affirmative action policies of the government, they may be more inclined to favour equitable distribution. In fact, in our sample, most of the SCST and OBC subjects in the sample have availed of the quota policy to gain admission into the university.

The coefficients on the other covariates are in the expected directions. For example, females in our sample are less likely to compete, less confident, and more risk averse (see Niederle 2014 for a recent review of gender differences in behavioural preferences); number of siblings is positively associated with being egalitarian; and those with higher cognitive ability (as measured by Raven's test score) are less risk averse.

In Table 3, we examine the determinants of personality traits: Big Five, locus of control, and grit, using the SUR framework. Except for emotional stability for which there are no caste differences, we find SCSTs to have lower scores on all other traits such as agreeableness, openness to experience, conscientiousness, extroversion, locus of control, as well as grit. While the OBCs are also less gritty, more introverted, and less open to experience, they do not differ 
from the upper castes on other measures such as locus of control, agreeableness, conscientiousness, and emotional stability. Further, we find SCST-OBC difference to be significant only for conscientiousness and locus of control and weakly significant for agreeableness. For the other traits, SCST-OBC differences are not significant at conventional levels. Given the importance of traits such as conscientiousness and locus of control in explaining labour market performance (Borghans et al. 2008; Cobb-Clark 2015), the wage and occupational disadvantage faced by SCSTs could be magnified due to a lower endowment of such traits. For example, in the case of the black-white wage gap in the US, Borghans, ter Weel, and Weinberg (2014) argue that a stagnation of the wage gap has been due to the increasing relevance of 'people skills' where minority groups may be at a disadvantage when interacting with majority because of prejudice or barriers to interpersonal communication on account of racial or cultural differences.

In terms of other covariates, we find females to be more agreeable and less emotionally stable, as also shown in the existing literature (Feingold 1994; Costa, Terracciano, and McCrae 2001). Females in our sample are also grittier and more conscientious. This is also reflected in for instance, a significant gender difference in class attendance in our sample such that the proportion of female students attending classes regularly is 73 per cent as compared to 64 per cent among males (two-sided t-test, p-value $=0.00$ ).

\subsection{Heterogeneity}

\subsubsection{Heterogeneity by gender}

We also examine whether these caste-based differences in traits and behaviour differ by gender. The literature on the gender-caste overlap indicates a trade-off such that while upper caste females tend to be materially better off, they are subjected to more restrictions on mobility due to purity concerns, as compared to low caste women who tend to face more liberal social norms and gender attitudes despite their material deprivation (Field, Jayachandran, and Pande 2010). ${ }^{7}$ For instance, Eswaran, Ramaswami, and Wadhwa (2013) find that controlling for wealth, women's time allocated to market work relative to that of men declines as one moves up the caste hierarchy. We check for gender-differentiated effects across castes by interacting the SCST and $\mathrm{OBC}$ dummies as well as the full vector of controls with the female dummy. The results of the SUR models are presented in Tables 4 and 5 for behavioural preferences and personality traits respectively. While for behavioural outcomes, we do not find the caste effects to vary by gender, among the personality traits, we find that females belonging to SCST and OBC castes exhibit higher levels of extroversion, thereby mitigating some of the overall caste gap observed for extroversion in Table 3.

\subsubsection{Heterogeneity by socioeconomic status}

Socioeconomic status has been previously shown to matter in the formation and development of traits and behaviour. Deckers et al. (2015) find that children from families with higher socioeconomic status (as measured by parental education and family income) are significantly more patient, less risk-seeking, and have higher IQ, and that the difference between children from high and low SES persists over time. Almas et al. (2015) find that socioeconomic status is linked with competitiveness and that the gender gap in competitiveness is observed only among children from well-off families. Therefore, exploring whether the caste effects vary by one's SES

\footnotetext{
7 Deshpande (2007), on the contrary, finds this trade-off to be disappearing and low caste women to be doubly disadvantaged as they are materially deprived and also suffer from immurement.
} 
constitutes a natural corollary to the above discussion. In Tables 6 and 7, we estimate SUR models for behaviour and personality respectively, wherein all controls and the caste dummies are interacted with a dummy for high SES. As mentioned earlier, high socioeconomic status takes a value 1 if both parents have a graduate or postgraduate degree or if monthly family income exceeds Rs. 50,000, 0 otherwise. For behavioural preferences, we do not observe any variation in the caste effects on the basis of SES. However, among the personality traits, we find that SCSTs and OBCs from high SES backgrounds have a more internal locus of control as compared to SCSTs and OBCs from less well-off families. This compensating effect is particularly interesting in light of the finding that locus of control is a robust determinant of life outcomes (Cobb-Clark 2015).

\subsubsection{Heterogeneity by private school attendance}

In Tables 8 and 9, we also explore heterogeneity by one's attendance in private school prior to joining college. Private schools are typically characterized by higher teacher-student ratios, lower teacher absenteeism, and generally better infrastructure as compared to public schools in India. Recent influential studies such as Muralidharan and Sundaraman (2015) find that private schools lead to better learning outcomes among students with a more efficient time use and at a lower average cost per student as compared to public schools in a large Indian state. Therefore, relative to public schools, private schools may also shape behavioural attitudes and personality traits of students differently, thereby bridging some of the pre-existing caste gaps documented earlier.

For behavioural preferences, we do not find the caste effects to differ by the type of high school attended. However, access to private school has compensatory effects on some personality traits. While in the overall sample, we do not find any caste differences in terms of emotional stability, SCSTs and OBCs who attended private school are more emotionally stable than those who did not. SCSTs that attended private school are relatively more agreeable than those who did not. Similarly, OBCs that attended private school are more conscientious and express a greater openness to experiences compared to OBCs that went to a public school. These results suggest that access to better environments in private schools could potentially foster a healthier development of personality traits among low caste groups. Finally, note that due to the high overlap between SES and private school enrolment, it is likely that family SES drives some of the private school enrolment effects.

\subsection{Robustness}

Since we examine caste-based differences among several behavioural outcomes and personality traits, the probability of attaining a false positive or type I error increases with the number of outcomes tested. To address this concern, we follow the method outlined in Kling, Liebman, and Katz (2007) and construct an index that combines all four behavioural outcomes and all seven personality trait variables. The eleven outcome variables are first standardized using the mean and standard deviation of the upper castes that serves as the reference category. We compute an index by taking an equally weighted average over all eleven standardized outcomes. We then estimate a simple OLS regression model with this index as the dependent variable. We include caste dummies and the full vector of controls $(\mathrm{X})$ that are common to the estimation of all the outcome variables. The associated results are reported in Table 10. We find that SCST and OBCs perform significantly worse than upper castes across all behaviour and personality measures by 0.17 standard deviations and 0.07 standard deviations respectively.

As a further check of our caste-based effects, we also compute average effect size using the method outlined in Clingingsmith, Khwaja, and Kremer (2009). The average effect size is constructed by taking a weighted average over the individual caste-based effects within a domain 
of related outcomes computed using SUR that improves the precision of the caste effects, thereby reducing type II errors. ${ }^{8}$ Results using this are very similar to those obtained in Table 10 and available from the authors upon request. Note however, that type II error concerns are low in our design to begin with, because of large sample size, and because SUR is our preferred estimation framework.

Further, as SUR models require information on all the outcome variables and right hand side variables to be jointly not missing, using this framework creates more missing observations than necessary. Therefore, we also estimate OLS regressions and find that the magnitude and direction of the OLS estimates reported in Appendix Tables A3 and A4 with more observations are quite similar to the corresponding SUR results with fewer observations (reported in Tables 2 and 3), ruling out any concerns related to missing data. ${ }^{9}$

\section{Conclusion}

The persistent economic gap between the upper and lower caste groups in India can be typically traced back to caste differences in endowments, unequal access to public services, and continued economic and social discrimination. In this paper, we explore another source that is associated with caste differences in economic outcomes, namely, caste-based differentials in behavioural preferences and personality traits. We find that SCSTs and OBCs fare worse than the upper castes along several dimensions of behaviour and personality that tend to have positive implications for not only educational attainment and labour market performance, but also life outcomes in general. Consequently, these differences are likely to exacerbate the already existing economic as well as social differences between the upper and lower caste groups.

Given the accumulation of cognitive and behavioural disadvantage among these excluded groups by the time they reach adulthood, our results suggest the need for redesigning the current structure of affirmative action policies in India. For example, given that racial gaps in cognitive and non-cognitive skills emerge early on and tend to persist, and that the relationship between non-cognitive skills and academic achievement is robust, there is a strong case for targeting early childhood interventions to supplement the familial resources-in terms of both financial resources and parental attention-for young children from disadvantaged backgrounds. This argument is also supported by Cunha, Heckman, Lochner, and Masterov (2006) who discuss that the highest returns to low-ability disadvantaged groups accrue based on early childhood programmes as compared to those only in late adolescence. They further stress the importance of following up on early childhood investments with complementary investments at later ages in order to reap the benefits of the former. In a similar vein, another policy option would be to invest in programmes that directly target the development of soft skills among disadvantaged individuals during their childhood and adolescence. ${ }^{10}$

\footnotetext{
${ }^{8}$ Note that this method only uses the full set of common controls included in all specifications.

${ }^{9}$ Less than 1 per cent of choices are missing for the behavioural preferences, except egalitarianism for which 1.5 per cent of the observations are missing. Less than 5 per cent of the Big-Five traits and grit are missing. About 7 per cent of the data on locus of control is missing. And between 1-2 per cent of the data on all other covariates is missing.

10 While there is evidence on this from the USA based on initiatives such as the Perry Preschool Program, more research is needed to test the efficacy of such programmes in developing countries. An exception is the recent work by Krishnan and Krutikova (2013) that finds positive effects on self-efficacy and self-esteem of an after-school noncognitive skill development programme among slum children in a large Indian city.
} 
At a broader level, there is also a case for fostering greater inter-caste contact that can help reduce biases and negative stereotypes, which have negative repercussions on self-confidence and self-esteem among low castes. More concerted multi-pronged policy efforts to making public spaces inclusive and facilitating interaction on equitable terms would be a start in this direction.

\section{References}

Akerlof, G.A., and R.E. Kranton (2010). Identity Economics: How our Identities Shape our Work, Wages, and Well-being. Princeton, NJ: Princeton University Press.

Alesina, A., and P. Giuliano (2011). 'Preferences for redistribution'. In J. Benhabib, A. Bisin, and M.O. Jackson (eds), Handbook of Social Economics, Vol. I, London: Elsevier.

Almas, I., A.W. Cappelen, K.G. Salvanes, E.O. Sorensen, and B. Tungodden (2015). 'Willingness to compete: family matters'. Management Science, forthcoming.

Bartling, B., E. Fehr, M.A. Maréchal, and D. Schunk (2009). 'Egalitarianism and competitiveness'. American Economic Review: Papers \& Proceedings, 99(2): 93-8.

Benjamin, D.J., J.J. Choi, and A.J. Strickland (2010). 'Social identity and preferences'. American Economic Review, 100: 1913-28.

Bertrand, M., and E. Duflo (2016). 'Field experiments in discrimination'. NBER Working Paper 22014. Cambridge, MA: NBER.

Borghans, L., A.L. Duckworth, J.J. Heckman, and B. ter Weel (2008). 'The economics and psychology of personality traits'. Journal of Human Resources, 43(4): 972-1059.

Borghans, L., B. ter Weel, and B.A. Weinberg (2014). 'People skills and the labor-market outcomes of underrepresented groups'. Industrial and Labor Relations Review, 67(2): 287-334.

Bros, C. (2014). 'The burden of caste on social identity in India'. Journal of Development Studies, 50(10): 1411-29.

Buser, T., M. Niederle, and H. Øosterbeek (2014). 'Gender, competitiveness and career choices'. Quarterly Journal of Economics, 129(3): 1409-47.

Clingingsmith, D., A.I. Khwaja, and M.R. Kremer (2009). 'Estimating the impact of the Hajj: Religion and tolerance in Islam's global gathering'. Quarterly Journal of Economics, 124(3): 1133-70.

Coate, S., and G.C. Loury (1993). 'Will affirmative action eliminate negative stereotypes?'. American Economic Review, 83(5): 1220-40.

Cobb-Clark, D.A. (2015). 'Locus of control and the labor market'. IZA Journal of Labor Economics, 4(3:) 1-19.

Costa, P.T., A. Terracciano, and R.R. McCrae (2001). 'Gender differences in personality traits across cultures: robust and surprising findings'. Journal of Personality and Social Psychology, 81(2): 322-31.

Cunha, F., J.J. Heckman, L. Lochner, and D.V. Masterov (2006). 'Interpreting the evidence on life cycle skill formation'. In E.A. Hanushek and F. Welch (eds), Handbook of the Economics of Education, Vol. I. London: Elsevier.

Deckers, T., A. Falk, F. Kosse, and H. Schildberg-Hörisch (2015). 'How does socio-economic status shape a child's personality?’. IZA Working Paper No. 8977. Bonn: IZA. 
Deshpande, A. (2007). 'Overlapping identities under liberalization: gender and caste in India'. Economic Development and Cultural Change, 55(4): 735-60.

Deshpande, A. (2011). The Grammar of Caste. Oxford: Oxford University Press.

Deshpande, A., and K. Newman (2007). 'Where the path leads: the role of caste in postuniversity employment expectations'. Economic and Political Weekly, 42(41): 4133-40.

Deshpande, A., and R. Ramachandran (2013). 'How backward are the other backward classes? Changing contours of caste disadvantage in India'. CDE Working Paper No. 233. Delhi: University of Delhi.

Deshpande, A., and S. Sharma (2013). 'Entrepreneurship or survival? Caste and gender of small business in India'. Economic and Political Weekly, XLVIII(28): 38-49.

Deshpande, A., and S. Sharma (2016). 'Disadvantage and discrimination in self-employment: Caste gaps in earnings in Indian small businesses'. Small Business Economics, 46(2): 325-46.

Duckworth, A.L, and P.D. Quinn(2009). 'Development and validation of the Short Grit Scale (Grit-S)'. Journal of Personality Assessment, 91: 166-74.

Eswaran, M., B. Ramaswami, and W. Wadhwa (2013). 'Status, caste, and the time allocation of women in rural India'. Economic Development and Cultural Change, 61(2): 311-33.

Feingold, A. (1994). 'Gender differences in personality: a meta-analysis'. Psychological Bulletin, 116(3): 429-56.

Field, E., S. Jayachandran, and R. Pande (2010). 'Do traditional institutions constrain female entrepreneurship? A field experiment on business training in India'. American Economic Review Papers \& Proceedings, 100(2): 125-9.

Gneezy, U., and J. Potters (1997). 'An experiment on risk taking and evaluation periods'. Quarterly Journal of Economics, 112(2): 631-45.

Gosling, S.D., P.J. Rentfrow, and W.B. Swann Jr. (2003). 'A very brief measure of the Big-Five personality domains'. Journal of Research in Personality, 37: 504-28.

Hanna, R., and L. Linden (2012). 'Discrimination in grading'. American Economic Journal: Economic Policy, 4(4): 146-68.

Hnatkovska, V., A. Lahiri, and S. Paul (2012). 'Castes and labor mobility'. American Economic Journal: Applied Economics, 4(2): 274-307.

Hoff, K., and P. Pandey (2006). 'Discrimination, social identity and durable inequalities'. American Economic Review: Papers \& Proceedings, 96(2): 206-11.

Hoff, K., and J.E. Stiglitz (2010). 'Equilibrium fictions: a cognitive approach to societal rigidity'. American Economic Review, 100(2): 141-6.

Jaspal, R. (2011). 'Caste, social stigma and identity processes'. Psychology and Developing Societies, 23(2): 27-62.

Kijima, Y. (2006). 'Caste and tribe inequality: evidence from India, 1983-1999'. Economic Development and Cultural Change, 54(2): 369-404.

Kling, J.R., J.B. Liebman, and L.F. Katz (2007). 'Experimental analysis of neighborhood effects'. Econometrica, 75(1): 83-119.

Krishnan, P., and S. Krutikova (2013). 'Non-cognitive skill formation in poor neighbourhoods of urban India'. Labour Economics, 24(C): 68-85. 
Kumar, S.M. (2013). 'Does access to formal agricultural credit depend on caste?'. World Development, 43: 315-28.

Mukherjee, P. (2015). 'The effects of social identity on aspirations and learning outcomes: a field experiment in rural India'. Working Paper.

Munshi, K., and M. Rosenzweig (2006). 'Traditional institutions meet the modern world: caste, gender, and schooling choice in a globalizing economy'. American Economic Review, 96(4): $1225-52$.

Muralidharan, K., and V. Sundaraman (2015). 'The aggregate effect of school choice: Evidence from a two-stage experiment in India'. Quarterly Journal of Economics, 130(3): 1011-66.

Niederle, M. (2014). ‘Gender'. NBER Working Paper No. 20788. Cambridge, MA: NBER.

Niederle, M., and L. Vesterlund (2007). 'Do women shy away from competition? Do men compete too much?'. Quarterly Journal of Economics, 122(3): 1067-101.

Orazem, P., and E. King (2008). 'Schooling in developing countries: the roles of supply, demand and government policy'. In T.P. Schultz, and J. Strauss (eds), Handbook of Development Economics, Volume 4, Amsterdam: North Holland Press.

Rotter, J.B. (1966). 'Generalized expectancies for internal versus external control of reinforcement'. Psychological Monographs: General and Applied, 80(1): 1-28

Sharma, S. (2015). 'Caste-based crimes and economic status: evidence from India'. Journal of Comparative Economics, 43(1): 204-26.

Siddique, Z. (2011). 'Evidence on caste-based discrimination'. Labour Economics, 18(1): S146-59.

Spears, D. (2016). 'Caste and life satisfaction in rural north India'. Economic and Political Weekly, LI(4): 12-14.

Steele, C.M., and J. Aronson (1995). 'Stereotype threat and the intellectual test performance of African Americans'. Journal of Personality and Social Psychology, 69(5): 797-811.

World Development Report (2015). Mind, Society and Behavior. Washington, DC: World Bank. 
Table 1: Summary Statistics by Caste

\begin{tabular}{|c|c|c|c|c|c|c|c|}
\hline Variables & $\begin{array}{l}\text { Pooled } \\
\text { (1) }\end{array}$ & $\begin{array}{c}\text { Upper } \\
\text { Caste } \\
\text { (2) }\end{array}$ & $\begin{array}{c}\text { OBC } \\
(3)\end{array}$ & $\begin{array}{c}\text { SCST } \\
\text { (4) }\end{array}$ & $\begin{array}{c}\text { UC vs } \\
\text { OBC } \\
\text { t-test } \\
(5)\end{array}$ & $\begin{array}{c}\text { UC vs } \\
\text { SCST } \\
\text { t-test } \\
(6)\end{array}$ & $\begin{array}{c}\text { OBC } \\
\text { vs } \\
\text { SCST } \\
\text { t-test } \\
(7)\end{array}$ \\
\hline \multicolumn{8}{|c|}{ Panel A: Behavioral traits } \\
\hline Competitiveness & $\begin{array}{c}0.31 \\
(0.46)\end{array}$ & $\begin{array}{c}0.31 \\
(0.46)\end{array}$ & $\begin{array}{c}0.32 \\
(0.46)\end{array}$ & $\begin{array}{c}0.31 \\
(0.46)\end{array}$ & 0.91 & 0.98 & 0.95 \\
\hline Confidence & $\begin{array}{c}0.32 \\
(0.46)\end{array}$ & $\begin{array}{c}0.31 \\
(0.46)\end{array}$ & $\begin{array}{c}0.38 \\
(0.48)\end{array}$ & $\begin{array}{c}0.28 \\
(0.45)\end{array}$ & 0.01 & 0.29 & 0.01 \\
\hline Risk attitude & $\begin{array}{c}46.78 \\
(18.86)\end{array}$ & $\begin{array}{c}46.18 \\
(18.39)\end{array}$ & $\begin{array}{l}48.18 \\
(20.15)\end{array}$ & $\begin{array}{c}48.22 \\
(19.62)\end{array}$ & 0.08 & 0.09 & 0.98 \\
\hline Egalitarianism & $\begin{array}{c}0.15 \\
(0.36)\end{array}$ & $\begin{array}{c}0.13 \\
(0.34)\end{array}$ & $\begin{array}{c}0.19 \\
(0.39)\end{array}$ & $\begin{array}{c}0.18 \\
(0.39)\end{array}$ & 0.01 & 0.03 & 0.84 \\
\hline \multicolumn{8}{|c|}{ Panel B: Personality traits } \\
\hline Extraversion & $\begin{array}{c}4.62 \\
(1.41)\end{array}$ & $\begin{array}{c}4.76 \\
(1.43)\end{array}$ & $\begin{array}{c}4.28 \\
(1.25)\end{array}$ & $\begin{array}{c}4.25 \\
(1.34)\end{array}$ & 0.00 & 0.00 & 0.77 \\
\hline Agreeableness & $\begin{array}{c}5.13 \\
(1.18)\end{array}$ & $\begin{array}{c}5.19 \\
(1.15)\end{array}$ & $\begin{array}{c}5.07 \\
(1.22)\end{array}$ & $\begin{array}{c}4.83 \\
(1.23)\end{array}$ & 0.08 & 0.00 & 0.02 \\
\hline Conscientiousness & $\begin{array}{c}5.27 \\
(1.27)\end{array}$ & $\begin{array}{c}5.29 \\
(1.27)\end{array}$ & $\begin{array}{c}5.31 \\
(1.29)\end{array}$ & $\begin{array}{c}5.11 \\
(1.26)\end{array}$ & 0.83 & 0.03 & 0.06 \\
\hline Emotional Stability & $\begin{array}{c}4.56 \\
(1.35)\end{array}$ & $\begin{array}{c}4.52 \\
(1.38)\end{array}$ & $\begin{array}{c}4.65 \\
(1.26)\end{array}$ & $\begin{array}{c}4.62 \\
(1.26)\end{array}$ & 0.14 & 0.3 & 0.76 \\
\hline $\begin{array}{l}\text { Openness to } \\
\text { experience }\end{array}$ & $\begin{array}{c}5.33 \\
(1.15)\end{array}$ & $\begin{array}{c}5.43 \\
(1.13)\end{array}$ & $\begin{array}{c}5.14 \\
(1.20)\end{array}$ & $\begin{array}{c}5.04 \\
(1.15)\end{array}$ & 0.00 & 0.00 & 0.29 \\
\hline Locus of control & $\begin{array}{c}7.29 \\
(2.02)\end{array}$ & $\begin{array}{c}7.27 \\
(2.11)\end{array}$ & $\begin{array}{c}7.51 \\
(1.76)\end{array}$ & $\begin{array}{c}7.19 \\
(1.79)\end{array}$ & 0.07 & 0.60 & 0.04 \\
\hline Grit & $\begin{array}{c}3.35 \\
(0.57)\end{array}$ & $\begin{array}{c}3.39 \\
(0.57)\end{array}$ & $\begin{array}{c}3.28 \\
(0.55)\end{array}$ & $\begin{array}{c}3.21 \\
(0.50)\end{array}$ & 0.00 & 0.00 & 0.14 \\
\hline \multicolumn{8}{|c|}{ Panel C: Control variables } \\
\hline Female & $\begin{array}{c}0.49 \\
(0.50)\end{array}$ & $\begin{array}{c}0.58 \\
(0.49)\end{array}$ & $\begin{array}{c}0.28 \\
(0.45)\end{array}$ & $\begin{array}{c}0.24 \\
(0.43)\end{array}$ & 0.00 & 0.00 & 0.27 \\
\hline Age & $\begin{array}{l}19.75 \\
(0.96)\end{array}$ & $\begin{array}{l}19.72 \\
(0.86)\end{array}$ & $\begin{array}{l}19.78 \\
(1.17)\end{array}$ & $\begin{array}{l}19.83 \\
(1.12)\end{array}$ & 0.35 & 0.07 & 0.57 \\
\hline Number of siblings & $\begin{array}{c}1.58 \\
(1.02)\end{array}$ & $\begin{array}{c}1.36 \\
(0.78)\end{array}$ & $\begin{array}{c}1.97 \\
(1.21)\end{array}$ & $\begin{array}{c}2.20 \\
(1.38)\end{array}$ & 0.00 & 0.00 & 0.03 \\
\hline Hindu & $\begin{array}{c}0.91 \\
(0.28)\end{array}$ & $\begin{array}{c}0.92 \\
(0.27)\end{array}$ & $\begin{array}{c}0.87 \\
(0.33)\end{array}$ & $\begin{array}{c}0.91 \\
(0.27)\end{array}$ & 0.006 & 0.88 & 0.07 \\
\hline Private school & $\begin{array}{c}0.70 \\
(0.46)\end{array}$ & $\begin{array}{c}0.82 \\
(0.38)\end{array}$ & $\begin{array}{c}0.52 \\
(0.50)\end{array}$ & $\begin{array}{c}0.31 \\
(0.46)\end{array}$ & 0.00 & 0.00 & 0.00 \\
\hline $\begin{array}{l}\text { High socioeconomic } \\
\text { status }\end{array}$ & $\begin{array}{c}0.71 \\
(0.45)\end{array}$ & $\begin{array}{c}0.82 \\
(0.38)\end{array}$ & $\begin{array}{l}0.46 \\
(0.5)\end{array}$ & $\begin{array}{c}0.37 \\
(0.48)\end{array}$ & 0.00 & 0.00 & 0.02 \\
\hline Employed mother & $\begin{array}{c}0.23 \\
(0.42)\end{array}$ & $\begin{array}{c}0.28 \\
(0.45)\end{array}$ & $\begin{array}{c}0.08 \\
(0.28)\end{array}$ & $\begin{array}{c}0.14 \\
(0.34)\end{array}$ & 0.00 & 0.00 & 0.04 \\
\hline
\end{tabular}




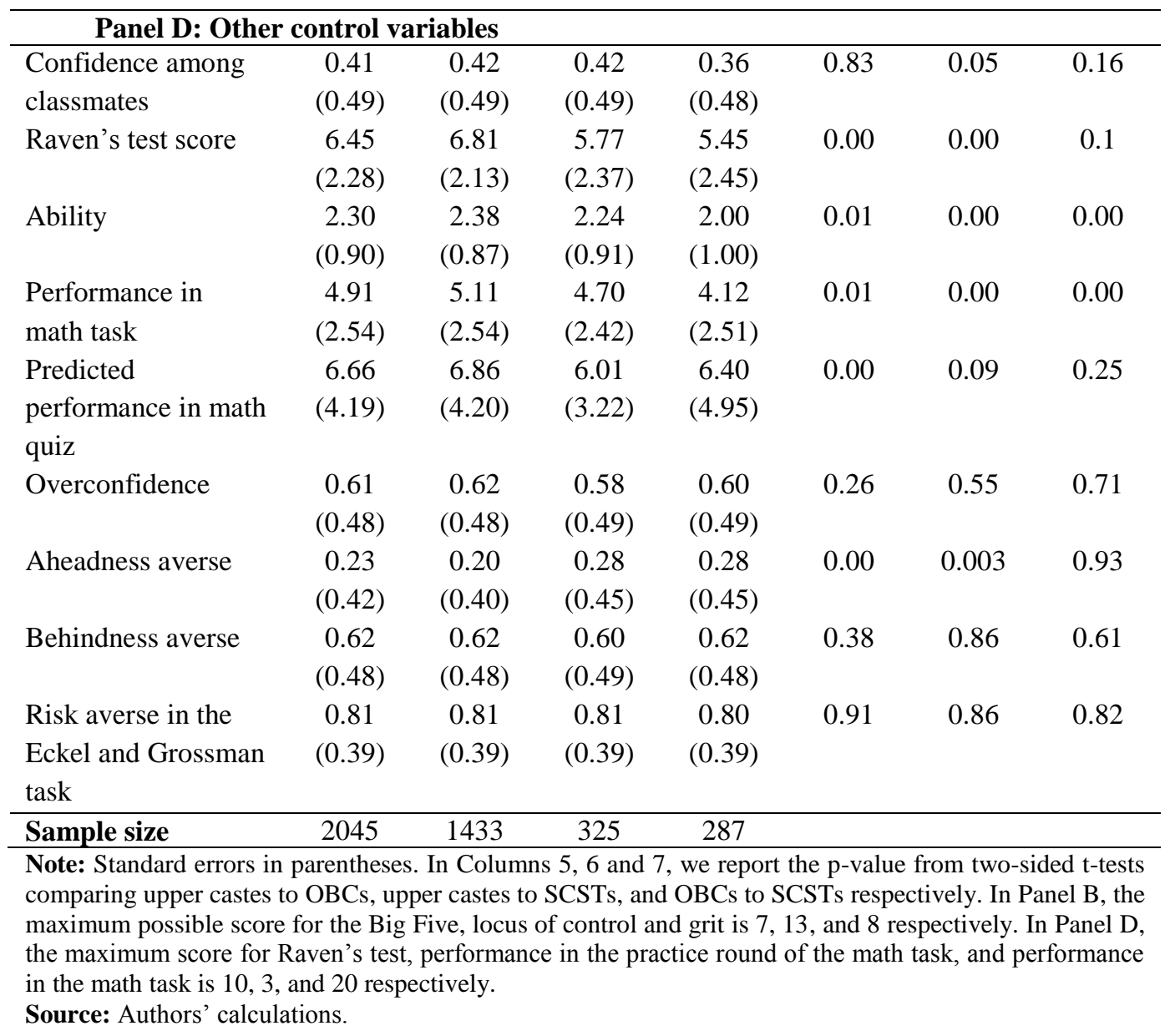


Table 2: SUR estimates: Behavioral Outcomes

\begin{tabular}{|c|c|c|c|c|}
\hline & $\begin{array}{c}\text { (1) } \\
\text { Competitiveness }\end{array}$ & $\begin{array}{c}(2) \\
\text { Confidence }\end{array}$ & $\begin{array}{c}\text { (3) } \\
\text { Risk attitude }\end{array}$ & $\begin{array}{c}\text { (4) } \\
\text { Egalitarianism } \\
\end{array}$ \\
\hline SCST & $\begin{array}{l}-0.065^{*} \\
(0.036)\end{array}$ & $\begin{array}{c}-0.079 * * \\
(0.038)\end{array}$ & $\begin{array}{c}0.993 \\
(1.521)\end{array}$ & $\begin{array}{l}0.058 * * \\
(0.029)\end{array}$ \\
\hline $\mathrm{OBC}$ & $\begin{array}{c}-0.075 * * \\
(0.032)\end{array}$ & $\begin{array}{c}0.030 \\
(0.034)\end{array}$ & $\begin{array}{l}-0.129 \\
(1.352)\end{array}$ & $\begin{array}{l}0.049 * \\
(0.026)\end{array}$ \\
\hline Female & $\begin{array}{c}-0.143 * * * \\
(0.023)\end{array}$ & $\begin{array}{c}-0.095 * * * \\
(0.023)\end{array}$ & $\begin{array}{c}-6.039 * * * \\
(0.919)\end{array}$ & $\begin{array}{c}0.004 \\
(0.018)\end{array}$ \\
\hline Age & $\begin{array}{c}0.001 \\
(0.012)\end{array}$ & $\begin{array}{c}0.003 \\
(0.013)\end{array}$ & $\begin{array}{c}0.056 \\
(0.515)\end{array}$ & $\begin{array}{l}-0.007 \\
(0.010)\end{array}$ \\
\hline Hindu & $\begin{array}{l}-0.065^{*} \\
(0.036)\end{array}$ & $\begin{array}{c}0.024 \\
(0.037)\end{array}$ & $\begin{array}{l}-1.114 \\
(1.485)\end{array}$ & $\begin{array}{l}-0.025 \\
(0.029)\end{array}$ \\
\hline Number of siblings & $\begin{array}{c}0.012 \\
(0.011)\end{array}$ & $\begin{array}{c}0.017 \\
(0.012)\end{array}$ & $\begin{array}{c}0.056 \\
(0.477)\end{array}$ & $\begin{array}{l}0.018 * \\
(0.009)\end{array}$ \\
\hline Private School & $\begin{array}{l}-0.049 * \\
(0.026)\end{array}$ & $\begin{array}{l}-0.022 \\
(0.027)\end{array}$ & $\begin{array}{l}1.045 \\
(1.094)\end{array}$ & $\begin{array}{c}0.066 * * * \\
(0.021)\end{array}$ \\
\hline High socioeconomic status & $\begin{array}{c}0.013 \\
(0.027)\end{array}$ & $\begin{array}{l}-0.000 \\
(0.028)\end{array}$ & $\begin{array}{c}0.543 \\
(1.109)\end{array}$ & $\begin{array}{l}-0.019 \\
(0.021)\end{array}$ \\
\hline Employed mother & $\begin{array}{c}0.017 \\
(0.025)\end{array}$ & $\begin{array}{l}-0.018 \\
(0.026)\end{array}$ & $\begin{array}{c}0.371 \\
(1.049)\end{array}$ & $\begin{array}{c}0.029 \\
(0.020)\end{array}$ \\
\hline Aheadness Averse & $\begin{array}{l}-0.032 \\
(0.025)\end{array}$ & & & \\
\hline Behindness Averse & $\begin{array}{l}-0.033 \\
(0.021)\end{array}$ & & & \\
\hline Risk-averse in Eckel-Grossman task & $\begin{array}{c}-0.102 * * * \\
(0.026)\end{array}$ & & & \\
\hline Confidence among classmates & $\begin{array}{c}0.102 * * * \\
(0.021)\end{array}$ & & & \\
\hline Overconfidence & $\begin{array}{l}-0.002 \\
(0.021)\end{array}$ & & & \\
\hline Ability & $\begin{array}{c}0.008 \\
(0.012)\end{array}$ & $\begin{array}{l}-0.001 \\
(0.013)\end{array}$ & & \\
\hline Raven's test score & $\begin{array}{c}0.012 \\
(0.011)\end{array}$ & & $\begin{array}{l}1.135 * * \\
(0.451)\end{array}$ & \\
\hline Predicted performance in math quiz & & $\begin{array}{c}0.007 * * * \\
(0.003)\end{array}$ & & \\
\hline Performance in the math task & & & $\begin{array}{c}0.253 \\
(0.172)\end{array}$ & \\
\hline Constant & $\begin{array}{c}0.656 * * \\
(0.269)\end{array}$ & $\begin{array}{c}0.278 \\
(0.281) \\
\end{array}$ & $\begin{array}{c}49.846 * * * \\
(11.192) \\
\end{array}$ & $\begin{array}{c}0.159 \\
(0.214)\end{array}$ \\
\hline $\begin{array}{l}\mathrm{H}_{0}: \mathrm{SCST}=\mathrm{OBC} \\
\text { (p-value) } \\
\text { Observations } \\
\text { R-squared }\end{array}$ & $\begin{array}{c}0.07 \\
(0.79) \\
1,872 \\
0.141\end{array}$ & $\begin{array}{l}7.19 \\
(0.01) \\
1,872 \\
0.069\end{array}$ & $\begin{array}{c}0.48 \\
(0.49) \\
1,872 \\
0.086\end{array}$ & $\begin{array}{c}0.09 \\
(0.76) \\
1,872 \\
0.064\end{array}$ \\
\hline
\end{tabular}

Note: All regressions include session fixed effects. Standard errors in parentheses. ${ }^{*} * \mathrm{p}<0.01,{ }^{*} \mathrm{p}<0.05,{ }^{*} \mathrm{p}<0.10$.

Source: Authors' calculations. 
Table 3: SUR estimates: Personality traits

\begin{tabular}{|c|c|c|c|c|c|c|c|}
\hline & $\begin{array}{c}\text { (1) } \\
\text { Agreeableness }\end{array}$ & $\begin{array}{c}(2) \\
\text { Extraversion }\end{array}$ & $\begin{array}{c}\text { (3) } \\
\text { Conscientiousness }\end{array}$ & $\begin{array}{c}(4) \\
\text { Emotional } \\
\text { Stability } \\
\end{array}$ & $\begin{array}{c}\text { (5) } \\
\text { Openness to } \\
\text { experience }\end{array}$ & $\begin{array}{c}\text { (6) } \\
\text { Locus of } \\
\text { control } \\
\end{array}$ & $\begin{array}{l}\text { (7) } \\
\text { Grit }\end{array}$ \\
\hline SCST & $\begin{array}{c}-0.200 * * \\
(0.089)\end{array}$ & $\begin{array}{c}-0.264 * * * * \\
(0.088)\end{array}$ & $\begin{array}{c}-0.289 * * * \\
(0.089)\end{array}$ & $\begin{array}{l}-0.076 \\
(0.090)\end{array}$ & $\begin{array}{c}-0.310 * * * \\
(0.087)\end{array}$ & $\begin{array}{c}-0.224 * * \\
(0.089)\end{array}$ & $\begin{array}{c}-0.304 * * * \\
(0.089)\end{array}$ \\
\hline $\mathrm{OBC}$ & $\begin{array}{l}-0.042 \\
(0.079)\end{array}$ & $\begin{array}{c}-0.270 * * * \\
(0.078)\end{array}$ & $\begin{array}{l}-0.004 \\
(0.079)\end{array}$ & $\begin{array}{c}-0.022 \\
(0.079)\end{array}$ & $\begin{array}{c}-0.221 * * * \\
(0.077)\end{array}$ & $\begin{array}{l}-0.030 \\
(0.079)\end{array}$ & $\begin{array}{c}-0.177 * * \\
(0.079)\end{array}$ \\
\hline Female & $\begin{array}{c}0.275 * * * \\
(0.052)\end{array}$ & $\begin{array}{c}0.071 \\
(0.052)\end{array}$ & $\begin{array}{r}0.125 * * \\
(0.053)\end{array}$ & $\begin{array}{c}-0.213 * * * \\
(0.053)\end{array}$ & $\begin{array}{c}0.038 \\
(0.052)\end{array}$ & $\begin{array}{c}-0.068 \\
(0.053)\end{array}$ & $\begin{array}{c}0.179 * * * \\
(0.053)\end{array}$ \\
\hline Age & $\begin{array}{l}-0.021 \\
(0.029)\end{array}$ & $\begin{array}{l}-0.028 \\
(0.029)\end{array}$ & $\begin{array}{c}0.024 \\
(0.029)\end{array}$ & $\begin{array}{c}-0.013 \\
(0.029)\end{array}$ & $\begin{array}{c}0.006 \\
(0.029)\end{array}$ & $\begin{array}{c}0.031 \\
(0.029)\end{array}$ & $\begin{array}{l}-0.012 \\
(0.029)\end{array}$ \\
\hline Hindu & $\begin{array}{c}-0.180 * * \\
(0.086)\end{array}$ & $\begin{array}{c}0.047 \\
(0.086)\end{array}$ & $\begin{array}{c}-0.033 \\
(0.087)\end{array}$ & $\begin{array}{c}-0.231 * * * \\
(0.088)\end{array}$ & $\begin{array}{c}-0.065 \\
(0.085)\end{array}$ & $\begin{array}{l}-0.030 \\
(0.087)\end{array}$ & $\begin{array}{l}-0.115 \\
(0.087)\end{array}$ \\
\hline Number of siblings & $\begin{array}{l}-0.030 \\
(0.028)\end{array}$ & $\begin{array}{c}0.009 \\
(0.028)\end{array}$ & $\begin{array}{c}0.055 * * \\
(0.028)\end{array}$ & $\begin{array}{c}0.029 \\
(0.028)\end{array}$ & $\begin{array}{c}0.004 \\
(0.027)\end{array}$ & $\begin{array}{l}-0.026 \\
(0.028)\end{array}$ & $\begin{array}{c}0.001 \\
(0.028)\end{array}$ \\
\hline Private School & $\begin{array}{l}-0.063 \\
(0.065)\end{array}$ & $\begin{array}{c}0.147 * * \\
(0.065)\end{array}$ & $\begin{array}{l}-0.057 \\
(0.065)\end{array}$ & $\begin{array}{c}-0.032 \\
(0.066)\end{array}$ & $\begin{array}{c}0.060 \\
(0.064)\end{array}$ & $\begin{array}{l}-0.107 \\
(0.065)\end{array}$ & $\begin{array}{l}-0.086 \\
(0.065)\end{array}$ \\
\hline High socioeconomic status & $\begin{array}{c}0.049 \\
(0.066)\end{array}$ & $\begin{array}{c}-0.023 \\
(0.065)\end{array}$ & $\begin{array}{l}-0.093 \\
(0.066)\end{array}$ & $\begin{array}{c}0.013 \\
(0.067)\end{array}$ & $\begin{array}{c}0.054 \\
(0.065)\end{array}$ & $\begin{array}{l}-0.073 \\
(0.066)\end{array}$ & $\begin{array}{l}-0.007 \\
(0.066)\end{array}$ \\
\hline Employed mother & $\begin{array}{l}-0.085 \\
(0.060)\end{array}$ & $\begin{array}{c}0.152 * * \\
(0.060)\end{array}$ & $\begin{array}{c}-0.133 * * \\
(0.061)\end{array}$ & $\begin{array}{c}-0.034 \\
(0.061)\end{array}$ & $\begin{array}{c}0.119 * * \\
(0.059)\end{array}$ & $\begin{array}{c}-0.094 \\
(0.061)\end{array}$ & $\begin{array}{c}0.042 \\
(0.061)\end{array}$ \\
\hline Constant & $\begin{array}{c}0.586 \\
(0.631)\end{array}$ & $\begin{array}{c}0.521 \\
(0.628)\end{array}$ & $\begin{array}{l}-0.077 \\
(0.635)\end{array}$ & $\begin{array}{c}0.573 \\
(0.639)\end{array}$ & $\begin{array}{c}0.158 \\
(0.621)\end{array}$ & $\begin{array}{c}0.046 \\
(0.635)\end{array}$ & $\begin{array}{c}0.654 \\
(0.634)\end{array}$ \\
\hline $\begin{array}{l}\mathrm{H}_{0}: \mathrm{SCST}=\mathrm{OBC} \\
(\mathrm{p} \text {-value) } \\
\text { Observations } \\
\text { R-squared }\end{array}$ & $\begin{array}{l}2.69 \\
(0.1) \\
1,632 \\
0.071\end{array}$ & $\begin{array}{c}0.00 \\
(0.96) \\
1,632 \\
0.079\end{array}$ & $\begin{array}{c}8.67 \\
(0.003) \\
1,632 \\
0.066\end{array}$ & $\begin{array}{c}0.32 \\
(0.57) \\
1,632 \\
0.054\end{array}$ & $\begin{array}{c}0.88 \\
(0.35) \\
1,632 \\
0.068\end{array}$ & $\begin{array}{c}4.05 \\
(0.04) \\
1,632 \\
0.064\end{array}$ & $\begin{array}{c}1.73 \\
(0.19) \\
1,632 \\
0.080\end{array}$ \\
\hline
\end{tabular}

Source: Authors' calculations. 
Table 4: SUR estimates: Differences in Behavioral Preferences by Gender

\begin{tabular}{|c|c|c|c|c|}
\hline & $\begin{array}{c}(1) \\
\text { Competitiveness }\end{array}$ & $\begin{array}{c}(2) \\
\text { Confidence }\end{array}$ & $\begin{array}{c}\text { (3) } \\
\text { Risk attitude }\end{array}$ & $\begin{array}{c}(4) \\
\text { Egalitarianism }\end{array}$ \\
\hline SCST & $\begin{array}{l}-0.022 \\
(0.045)\end{array}$ & $\begin{array}{c}-0.091 * * \\
(0.047)\end{array}$ & $\begin{array}{c}0.989 \\
(1.867)\end{array}$ & $\begin{array}{c}0.094 * * * \\
(0.036)\end{array}$ \\
\hline $\mathrm{OBC}$ & $\begin{array}{l}-0.058 \\
(0.040)\end{array}$ & $\begin{array}{c}0.005 \\
(0.041)\end{array}$ & $\begin{array}{l}-0.759 \\
(1.663)\end{array}$ & $\begin{array}{c}0.067 * * \\
(0.032)\end{array}$ \\
\hline Female & $\begin{array}{l}-0.525 \\
(0.463)\end{array}$ & $\begin{array}{l}-0.241 \\
(0.485)\end{array}$ & $\begin{array}{c}-4.324 \\
(19.242)\end{array}$ & $\begin{array}{l}-0.006 \\
(0.368)\end{array}$ \\
\hline Female x SCST & $\begin{array}{l}-0.075 \\
(0.077)\end{array}$ & $\begin{array}{c}0.040 \\
(0.080)\end{array}$ & $\begin{array}{l}-0.342 \\
(3.228)\end{array}$ & $\begin{array}{l}-0.102 * \\
(0.061)\end{array}$ \\
\hline Female x OBC & $\begin{array}{l}-0.033 \\
(0.067)\end{array}$ & $\begin{array}{c}0.082 \\
(0.070)\end{array}$ & $\begin{array}{c}1.931 \\
(2.811)\end{array}$ & $\begin{array}{l}-0.039 \\
(0.054)\end{array}$ \\
\hline Constant & $\begin{array}{l}0.757^{* *} \\
(0.310)\end{array}$ & $\begin{array}{c}0.261 \\
(0.325)\end{array}$ & $\begin{array}{c}48.673 * * * \\
(12.876)\end{array}$ & $\begin{array}{c}0.164 \\
(0.245)\end{array}$ \\
\hline Observations & 1,872 & 1,872 & 1,872 & 1,872 \\
\hline R-squared & 0.151 & 0.072 & 0.089 & 0.067 \\
\hline
\end{tabular}


Table 5: SUR estimates: Differences in Personality Traits by Gender

\begin{tabular}{|c|c|c|c|c|c|c|c|}
\hline & $\begin{array}{c}(1) \\
\text { Agreeableness }\end{array}$ & $\begin{array}{c}(2) \\
\text { Extraversion }\end{array}$ & $\begin{array}{c}\text { (3) } \\
\text { Conscientiousness }\end{array}$ & $\begin{array}{c}(4) \\
\text { Emotional } \\
\text { Stability } \\
\end{array}$ & $\begin{array}{c}\text { (5) } \\
\text { Openness to } \\
\text { experience }\end{array}$ & $\begin{array}{c}(6) \\
\text { Locus of } \\
\text { control } \\
\end{array}$ & $\begin{array}{l}\text { (7) } \\
\text { Grit }\end{array}$ \\
\hline SCST & $\begin{array}{c}-0.286 * * * \\
(0.110)\end{array}$ & $\begin{array}{c}-0.444 * * * \\
(0.109)\end{array}$ & $\begin{array}{c}-0.288 * * * \\
(0.110)\end{array}$ & $\begin{array}{l}-0.078 \\
(0.111)\end{array}$ & $\begin{array}{c}-0.355^{* * * *} \\
(0.108)\end{array}$ & $\begin{array}{c}-0.319 * * * \\
(0.110)\end{array}$ & $\begin{array}{c}-0.321 * * * \\
(0.110)\end{array}$ \\
\hline $\mathrm{OBC}$ & $\begin{array}{l}-0.072 \\
(0.096)\end{array}$ & $\begin{array}{c}-0.409 * * * \\
(0.096)\end{array}$ & $\begin{array}{l}-0.026 \\
(0.097)\end{array}$ & $\begin{array}{l}-0.086 \\
(0.098)\end{array}$ & $\begin{array}{c}-0.246^{* * *} \\
(0.095)\end{array}$ & $\begin{array}{l}-0.063 \\
(0.097)\end{array}$ & $\begin{array}{l}-0.141 \\
(0.097)\end{array}$ \\
\hline Female & $\begin{array}{c}3.600 * * * \\
(1.089)\end{array}$ & $\begin{array}{l}-0.325 \\
(1.080)\end{array}$ & $\begin{array}{l}1.428 \\
(1.098)\end{array}$ & $\begin{array}{c}0.559 \\
(1.105)\end{array}$ & $\begin{array}{c}0.103 \\
(1.074)\end{array}$ & $\begin{array}{c}1.009 \\
(1.097)\end{array}$ & $\begin{array}{l}-1.024 \\
(1.097)\end{array}$ \\
\hline Female x SCST & $\begin{array}{c}0.238 \\
(0.185)\end{array}$ & $\begin{array}{c}0.413 * * \\
(0.184)\end{array}$ & $\begin{array}{c}0.012 \\
(0.187)\end{array}$ & $\begin{array}{l}-0.015 \\
(0.188)\end{array}$ & $\begin{array}{c}0.173 \\
(0.182)\end{array}$ & $\begin{array}{c}0.250 \\
(0.186)\end{array}$ & $\begin{array}{c}0.070 \\
(0.186)\end{array}$ \\
\hline Female x OBC & $\begin{array}{l}0.040 \\
(0.163)\end{array}$ & $\begin{array}{l}0.318^{* *} \\
(0.162)\end{array}$ & $\begin{array}{c}0.093 \\
(0.164)\end{array}$ & $\begin{array}{c}0.209 \\
(0.165)\end{array}$ & $\begin{array}{l}0.068 \\
(0.161)\end{array}$ & $\begin{array}{c}0.085 \\
(0.164)\end{array}$ & $\begin{array}{l}-0.126 \\
(0.164)\end{array}$ \\
\hline Constant & $\begin{array}{l}-0.510 \\
(0.727)\end{array}$ & $\begin{array}{c}0.761 \\
(0.721)\end{array}$ & $\begin{array}{l}-0.630 \\
(0.733)\end{array}$ & $\begin{array}{c}0.251 \\
(0.737)\end{array}$ & $\begin{array}{c}0.128 \\
(0.717)\end{array}$ & $\begin{array}{l}-0.398 \\
(0.733)\end{array}$ & $\begin{array}{c}1.174 \\
(0.732)\end{array}$ \\
\hline Observations & 1,632 & 1,632 & 1,632 & 1,632 & 1,632 & 1,632 & 1,632 \\
\hline R-squared & 0.078 & 0.090 & 0.070 & 0.058 & 0.071 & 0.068 & 0.084 \\
\hline
\end{tabular}


Table 6: SUR estimates: Differences in Behavioral Preferences by Socioeconomic Status

\begin{tabular}{|c|c|c|c|c|}
\hline & $\begin{array}{c}\text { (1) } \\
\text { Competitiveness }\end{array}$ & $\begin{array}{c}(2) \\
\text { Confidence }\end{array}$ & $\begin{array}{c}(3) \\
\text { Risk attitude }\end{array}$ & $\begin{array}{c}\text { (4) } \\
\text { Egalitarianism } \\
\end{array}$ \\
\hline SCST & $\begin{array}{l}-0.075 \\
(0.053)\end{array}$ & $\begin{array}{l}-0.062 \\
(0.055)\end{array}$ & $\begin{array}{c}0.756 \\
(2.219)\end{array}$ & $\begin{array}{c}0.083 * * \\
(0.042)\end{array}$ \\
\hline $\mathrm{OBC}$ & $\begin{array}{l}-0.039 \\
(0.049)\end{array}$ & $\begin{array}{l}0.087 * \\
(0.051)\end{array}$ & $\begin{array}{l}-0.173 \\
(2.080)\end{array}$ & $\begin{array}{c}0.090 * * \\
(0.039)\end{array}$ \\
\hline High SES & $\begin{array}{c}-0.977 * * \\
(0.462)\end{array}$ & $\begin{array}{c}0.574 \\
(0.484)\end{array}$ & $\begin{array}{c}10.886 \\
(19.108)\end{array}$ & $\begin{array}{c}0.121 \\
(0.364)\end{array}$ \\
\hline High SES x SCST & $\begin{array}{c}0.001 \\
(0.073)\end{array}$ & $\begin{array}{l}-0.003 \\
(0.076)\end{array}$ & $\begin{array}{c}0.424 \\
(3.066)\end{array}$ & $\begin{array}{l}-0.041 \\
(0.058)\end{array}$ \\
\hline High SES x OBC & $\begin{array}{l}-0.061 \\
(0.065)\end{array}$ & $\begin{array}{l}-0.097 \\
(0.067)\end{array}$ & $\begin{array}{c}0.564 \\
(2.707)\end{array}$ & $\begin{array}{l}-0.068 \\
(0.052)\end{array}$ \\
\hline Constant & $\begin{array}{l}1.121 * * * \\
(0.355)\end{array}$ & $\begin{array}{l}-0.031 \\
(0.373)\end{array}$ & $\begin{array}{c}42.921 * * * \\
(14.797)\end{array}$ & $\begin{array}{c}0.069 \\
(0.280)\end{array}$ \\
\hline $\begin{array}{l}\text { Observations } \\
\text { R-squared }\end{array}$ & $\begin{array}{l}1,872 \\
0.153\end{array}$ & $\begin{array}{l}1,872 \\
0.074\end{array}$ & $\begin{array}{l}1,872 \\
0.091\end{array}$ & $\begin{array}{l}1,872 \\
0.066\end{array}$ \\
\hline
\end{tabular}

Note: The regressions include session fixed effects. Standard errors in parentheses. $* * * \mathrm{p}<0.01, * * \mathrm{p}<0.05$, * $\mathrm{p}<0.10$. Controls include the full set of RHS variables (included in Columns 1-4 in Table 3) along with their interactions with the dummy for high socioeconomic status (SES).

Source: Authors' calculation.

Table 7: SUR estimates: Differences in Personality Traits by Socioeconomic Status

\begin{tabular}{|c|c|c|c|c|c|c|c|}
\hline & $\begin{array}{c}\text { (1) } \\
\text { Agreeableness }\end{array}$ & $\begin{array}{c}(2) \\
\text { Extraversion }\end{array}$ & $\begin{array}{c}\text { (3) } \\
\text { Conscientiousness }\end{array}$ & $\begin{array}{c}(4) \\
\text { Emotional } \\
\text { Stability }\end{array}$ & $\begin{array}{l}\text { (5) } \\
\text { Openness to } \\
\text { experience }\end{array}$ & $\begin{array}{c}(6) \\
\text { Locus of } \\
\text { control }\end{array}$ & $\begin{array}{l}\text { (7) } \\
\text { Grit }\end{array}$ \\
\hline SCST & $\begin{array}{l}-0.227 * \\
(0.128)\end{array}$ & $\begin{array}{l}-0.191 \\
(0.127)\end{array}$ & $\begin{array}{l}-0.219 * \\
(0.128)\end{array}$ & $\begin{array}{l}-0.194 \\
(0.129)\end{array}$ & $\begin{array}{l}-0.214^{*} \\
(0.125)\end{array}$ & $\begin{array}{c}-0.405^{* * *} \\
(0.128)\end{array}$ & $\begin{array}{c}-0.309 * * \\
(0.128)\end{array}$ \\
\hline OBC & $\begin{array}{l}-0.089 \\
(0.121)\end{array}$ & $\begin{array}{l}-0.206^{*} \\
(0.120)\end{array}$ & $\begin{array}{c}0.014 \\
(0.122)\end{array}$ & $\begin{array}{l}-0.137 \\
(0.122)\end{array}$ & $\begin{array}{l}-0.184 \\
(0.119)\end{array}$ & $\begin{array}{c}-0.240 * * \\
(0.122)\end{array}$ & $\begin{array}{l}-0.157 \\
(0.122)\end{array}$ \\
\hline High SES & $\begin{array}{l}2.289 * * \\
(1.087)\end{array}$ & $\begin{array}{l}-0.685 \\
(1.079)\end{array}$ & $\begin{array}{c}0.070 \\
(1.095)\end{array}$ & $\begin{array}{l}2.233 * * \\
(1.100)\end{array}$ & $\begin{array}{l}-0.930 \\
(1.070)\end{array}$ & $\begin{array}{l}-0.003 \\
(1.094)\end{array}$ & $\begin{array}{l}-1.234 \\
(1.094)\end{array}$ \\
\hline $\begin{array}{l}\text { High SES x } \\
\text { SCST }\end{array}$ & 0.089 & -0.203 & -0.131 & 0.264 & -0.182 & $0.299 *$ & -0.009 \\
\hline $\begin{array}{l}\text { High SES } x \\
\text { OBC }\end{array}$ & $\begin{array}{c}(0.179) \\
0.087\end{array}$ & $\begin{array}{l}(0.178) \\
-0.093\end{array}$ & $\begin{array}{l}(0.181) \\
-0.013\end{array}$ & $\begin{array}{c}(0.181) \\
0.187\end{array}$ & $\begin{array}{l}(0.176) \\
-0.041\end{array}$ & $\begin{array}{c}(0.180) \\
0.344 * *\end{array}$ & $\begin{array}{l}(0.180) \\
-0.051\end{array}$ \\
\hline Constant & $\begin{array}{c}(0.157) \\
-0.548 \\
(0.832)\end{array}$ & $\begin{array}{c}(0.156) \\
0.777 \\
(0.826)\end{array}$ & $\begin{array}{c}(0.158) \\
-0.271 \\
(0.838)\end{array}$ & $\begin{array}{c}(0.159) \\
-0.522 \\
(0.842)\end{array}$ & $\begin{array}{c}(0.155) \\
0.564 \\
(0.819)\end{array}$ & $\begin{array}{c}(0.158) \\
0.058 \\
(0.837)\end{array}$ & $\begin{array}{c}(0.158) \\
1.364 \\
(0.837)\end{array}$ \\
\hline $\begin{array}{l}\text { Observations } \\
\text { R-squared }\end{array}$ & $\begin{array}{l}1,632 \\
0.076\end{array}$ & $\begin{array}{l}1,632 \\
0.087 \\
\end{array}$ & $\begin{array}{l}1,632 \\
0.070\end{array}$ & $\begin{array}{l}1,632 \\
0.060 \\
\end{array}$ & $\begin{array}{l}1,632 \\
0.072 \\
\end{array}$ & $\begin{array}{l}1,632 \\
0.068\end{array}$ & $\begin{array}{l}1,632 \\
0.083\end{array}$ \\
\hline
\end{tabular}

Note: The regressions include session fixed effects. Standard errors in parentheses. $* * * p<0.01, * * p<0.05, * p<0.10$. Controls include the full-set of RHS variables (included in Columns 1-7 in Table 4) along with their interactions with the dummy for high socioeconomic status (SES).

Source: Authors' calculations. 
Table 8: SUR estimates: Differences in Behavioral Preferences by Private School Enrollment

\begin{tabular}{|c|c|c|c|c|}
\hline & $\begin{array}{c}\text { (1) } \\
\text { Competitiveness }\end{array}$ & $\begin{array}{c}(2) \\
\text { Confidence }\end{array}$ & $\begin{array}{c}\text { (3) } \\
\text { Risk attitude }\end{array}$ & $\begin{array}{c}\text { (4) } \\
\text { Egalitarianism }\end{array}$ \\
\hline SCST & $\begin{array}{c}-0.109 * * \\
(0.052)\end{array}$ & $\begin{array}{l}-0.067 \\
(0.053)\end{array}$ & $\begin{array}{c}0.790 \\
(2.143)\end{array}$ & $\begin{array}{c}0.038 \\
(0.041)\end{array}$ \\
\hline OBC & $\begin{array}{l}-0.070 \\
(0.053)\end{array}$ & $\begin{array}{c}0.025 \\
(0.054)\end{array}$ & $\begin{array}{l}-2.558 \\
(2.169)\end{array}$ & $\begin{array}{c}0.046 \\
(0.042)\end{array}$ \\
\hline Private school & $\begin{array}{l}-0.108 \\
(0.473)\end{array}$ & $\begin{array}{c}0.698 \\
(0.493)\end{array}$ & $\begin{array}{c}11.626 \\
(19.543)\end{array}$ & $\begin{array}{c}0.316 \\
(0.372)\end{array}$ \\
\hline SCST $\mathrm{x}$ private school & $\begin{array}{c}0.114 \\
(0.074)\end{array}$ & $\begin{array}{l}-0.025 \\
(0.076)\end{array}$ & $\begin{array}{l}-0.092 \\
(3.064)\end{array}$ & $\begin{array}{c}0.061 \\
(0.058)\end{array}$ \\
\hline OBC $x$ private school & $\begin{array}{l}-0.008 \\
(0.066)\end{array}$ & $\begin{array}{c}0.014 \\
(0.068)\end{array}$ & $\begin{array}{c}4.113 \\
(2.723)\end{array}$ & $\begin{array}{c}0.002 \\
(0.052)\end{array}$ \\
\hline Constant & $\begin{array}{l}0.726^{*} \\
(0.401)\end{array}$ & $\begin{array}{l}-0.225 \\
(0.420)\end{array}$ & $\begin{array}{l}41.876^{* *} \\
(16.742)\end{array}$ & $\begin{array}{c}0.004 \\
(0.317)\end{array}$ \\
\hline Observations & 1,872 & 1,872 & 1,872 & 1,872 \\
\hline R-squared & 0.148 & 0.076 & 0.091 & 0.067 \\
\hline
\end{tabular}

\section{Table 9: SUR estimates: Differences in Personality Traits by Private School Enrollment}

\begin{tabular}{|c|c|c|c|c|c|c|c|}
\hline & $\begin{array}{c}\text { (1) } \\
\text { Agreeableness }\end{array}$ & $\begin{array}{c}(2) \\
\text { Extraversion }\end{array}$ & $\begin{array}{c}\text { (3) } \\
\text { Conscientiou } \\
\text { sness }\end{array}$ & $\begin{array}{c}(4) \\
\text { Emotional } \\
\text { Stability }\end{array}$ & $\begin{array}{c}\text { (5) } \\
\text { Openness to } \\
\text { experience }\end{array}$ & $\begin{array}{c}(6) \\
\text { Locus of } \\
\text { control }\end{array}$ & $\begin{array}{l}\text { (7) } \\
\text { Grit }\end{array}$ \\
\hline SCST & $\begin{array}{c}-0.436 * * * \\
(0.124)\end{array}$ & $\begin{array}{c}-0.339 * * * \\
(0.124)\end{array}$ & $\begin{array}{c}-0.359 * * * \\
(0.125)\end{array}$ & $\begin{array}{c}-0.340 * * * \\
(0.126)\end{array}$ & $\begin{array}{c}-0.339 * * * \\
(0.122)\end{array}$ & $\begin{array}{c}-0.372 * * * \\
(0.125)\end{array}$ & $\begin{array}{c}-0.312 * * \\
(0.125)\end{array}$ \\
\hline OBC & $\begin{array}{l}-0.193 \\
(0.124)\end{array}$ & $\begin{array}{c}-0.273 * * \\
(0.124)\end{array}$ & $\begin{array}{l}-0.159 \\
(0.125)\end{array}$ & $\begin{array}{c}-0.217 * \\
(0.126)\end{array}$ & $\begin{array}{c}-0.389 * * * \\
(0.122)\end{array}$ & $\begin{array}{l}-0.185 \\
(0.125)\end{array}$ & $\begin{array}{c}-0.199 \\
(0.125)\end{array}$ \\
\hline Private school & $\begin{array}{c}1.335 \\
(1.128)\end{array}$ & $\begin{array}{l}-0.924 \\
(1.125)\end{array}$ & $\begin{array}{c}0.478 \\
(1.138)\end{array}$ & $\begin{array}{c}0.468 \\
(1.144)\end{array}$ & $\begin{array}{l}-1.539 \\
(1.111)\end{array}$ & $\begin{array}{c}0.925 \\
(1.138)\end{array}$ & $\begin{array}{l}-0.281 \\
(1.139)\end{array}$ \\
\hline SCST $x$ private school & $\begin{array}{c}0.464 * * * \\
(0.178)\end{array}$ & $\begin{array}{c}0.148 \\
(0.178)\end{array}$ & $\begin{array}{c}0.130 \\
(0.180)\end{array}$ & $\begin{array}{c}0.510 * * * \\
(0.181)\end{array}$ & $\begin{array}{c}0.040 \\
(0.175)\end{array}$ & $\begin{array}{c}0.285 \\
(0.180)\end{array}$ & $\begin{array}{l}-0.001 \\
(0.180)\end{array}$ \\
\hline OBC $\mathrm{x}$ private school & $\begin{array}{c}0.224 \\
(0.158)\end{array}$ & $\begin{array}{l}-0.013 \\
(0.157)\end{array}$ & $\begin{array}{l}0.261 * \\
(0.159)\end{array}$ & $\begin{array}{l}0.286^{*} \\
(0.160)\end{array}$ & $\begin{array}{l}0.271 * \\
(0.155)\end{array}$ & $\begin{array}{c}0.242 \\
(0.159)\end{array}$ & $\begin{array}{c}0.034 \\
(0.159)\end{array}$ \\
\hline Constant & $\begin{array}{l}-0.322 \\
(0.971)\end{array}$ & $\begin{array}{c}1.314 \\
(0.968)\end{array}$ & $\begin{array}{l}-0.424 \\
(0.980)\end{array}$ & $\begin{array}{c}0.244 \\
(0.985)\end{array}$ & $\begin{array}{c}1.209 \\
(0.956)\end{array}$ & $\begin{array}{l}-0.646 \\
(0.980)\end{array}$ & $\begin{array}{c}0.823 \\
(0.981)\end{array}$ \\
\hline Observations & 1,632 & 1,632 & 1,632 & 1,632 & 1,632 & 1,632 & 1,632 \\
\hline R-squared & 0.080 & 0.083 & 0.071 & 0.060 & 0.075 & 0.067 & 0.081 \\
\hline
\end{tabular}

Note: The regressions include session fixed effects. Standard errors in parentheses. $* * * p<0.01, * * p<0.05$, ${ }^{*} p<0.10$. Controls include fullset of RHS variables (included in Columns 1-7 in Table 4) along with their interactions with the dummy for private school.

Source: Authors' calculations. 
Table 10: Estimating average effect sizes

\begin{tabular}{lc}
\hline & Behavior \& personality index \\
\hline SCST & $-0.174 * * *$ \\
& $(0.035)$ \\
OBC & $-0.075^{* *}$ \\
& $(0.033)$ \\
Constant & 0.279 \\
& $(0.222)$ \\
& \\
\hline Observations & 1,598 \\
R-squared & 0.082
\end{tabular}

Note: Standard errors in parentheses are clustered at the session level. Controls include age, gender, religion, number of siblings, private school, high socioeconomic status, employed mother, and session dummies. $* * *$ $\mathrm{p}<0.01, * * \mathrm{p}<0.05, * \mathrm{p}<0.10$.

Source: Authors' calculations. 


\section{Appendix A}

Table A1: Correlation matrix of residuals for behavioral outcomes

\begin{tabular}{|c|c|c|c|c|}
\hline & Competitiveness & Confidence & Risk Attitude & Egalitarianism \\
\hline Competitiveness & 1.00 & & & \\
\hline Confidence & 0.055 & 1.00 & & \\
\hline Risk Attitude & 0.045 & 0.057 & 1.00 & \\
\hline Egalitarianism & -0.016 & -0.041 & -0.062 & 1.00 \\
\hline $\begin{array}{l}\text { Breusch-Pagan test of } \\
\text { independence: chi } 2 \\
\text { (p-value) }\end{array}$ & \multicolumn{4}{|c|}{$\begin{array}{c}26.34 \\
(0.0002)\end{array}$} \\
\hline
\end{tabular}

Table A2: Correlation matrix of residuals for personality traits

\begin{tabular}{|c|c|c|c|c|c|c|c|}
\hline & $\begin{array}{l}\text { Agreeable } \\
\text { ness }\end{array}$ & $\begin{array}{l}\text { Extro- } \\
\text { version }\end{array}$ & $\begin{array}{l}\text { Conscienti } \\
\text { ousness }\end{array}$ & $\begin{array}{l}\text { Emotional } \\
\text { Stability }\end{array}$ & $\begin{array}{l}\text { Openness } \\
\text { to } \\
\text { Experience }\end{array}$ & $\begin{array}{l}\text { Locus of } \\
\text { control }\end{array}$ & Grit \\
\hline Agreeableness & 1.00 & & & & & & \\
\hline Extroversion & -0.083 & 1.00 & & & & & \\
\hline Conscientiousness & 0.16 & -0.068 & 1.00 & & & & \\
\hline $\begin{array}{l}\text { Emotional } \\
\text { Stability }\end{array}$ & 0.20 & 0.0005 & 0.126 & 1.00 & & & \\
\hline $\begin{array}{l}\text { Openness to } \\
\text { Experience }\end{array}$ & 0.087 & 0.244 & 0.109 & 0.041 & 1.00 & & \\
\hline Locus of Control & 0.068 & 0.04 & 0.048 & 0.082 & 0.093 & 1.00 & \\
\hline Grit & 0.12 & 0.078 & 0.282 & 0.173 & 0.151 & 0.135 & 1.00 \\
\hline $\begin{array}{l}\text { Breusch-Pagan } \\
\text { test of } \\
\text { independence: } \\
\text { chi2 (p-value) }\end{array}$ & & & & $\begin{array}{l}599.91 \\
(0.00)\end{array}$ & & & \\
\hline
\end{tabular}

Source: Authors' calculations. 
Table A3: OLS and Probit estimates: Behavioral Preferences

\begin{tabular}{|c|c|c|c|c|}
\hline & $\begin{array}{c}\text { (1) } \\
\text { Competitiveness }\end{array}$ & $\begin{array}{c}\text { (2) } \\
\text { Confidence }\end{array}$ & $\begin{array}{c}\text { (3) } \\
\text { Risk Attitude }\end{array}$ & $\begin{array}{c}\text { (4) } \\
\text { Egalitarian }\end{array}$ \\
\hline SCST & $\begin{array}{l}-0.062 \\
(0.041)\end{array}$ & $\begin{array}{c}-0.096^{* * *} \\
(0.033)\end{array}$ & $\begin{array}{c}0.777 \\
(1.391)\end{array}$ & $\begin{array}{c}0.063 * * \\
(0.030)\end{array}$ \\
\hline OBC & $\begin{array}{c}-0.076 * * \\
(0.036)\end{array}$ & $\begin{array}{c}0.043 \\
(0.036)\end{array}$ & $\begin{array}{c}0.232 \\
(1.438)\end{array}$ & $\begin{array}{l}0.052 * \\
(0.029)\end{array}$ \\
\hline $\begin{array}{l}\text { Observations } \\
\text { R-squared }\end{array}$ & 1,852 & 1,933 & $\begin{array}{l}1,950 \\
0.080\end{array}$ & 1,890 \\
\hline
\end{tabular}

Table A4: OLS estimates: Personality Traits

\begin{tabular}{|c|c|c|c|c|c|c|c|}
\hline & $\begin{array}{c}(1) \\
\text { Agreeableness }\end{array}$ & $\begin{array}{c}(2) \\
\text { Extraversion }\end{array}$ & $\begin{array}{c}\text { (3) } \\
\text { Conscientiousnes } \\
\text { s }\end{array}$ & $\begin{array}{c}\text { (4) } \\
\text { Emotional } \\
\text { Stability }\end{array}$ & $\begin{array}{c}\text { (5) } \\
\text { Openness to } \\
\text { experience }\end{array}$ & $\begin{array}{c}\text { (6) } \\
\text { Locus of } \\
\text { control }\end{array}$ & $\begin{array}{l}(7) \\
\text { Grit }\end{array}$ \\
\hline SCST & $\begin{array}{l}-0.169 * \\
(0.097)\end{array}$ & $\begin{array}{c}-0.278 * * * \\
(0.098)\end{array}$ & $\begin{array}{c}-0.212 * * * \\
(0.077)\end{array}$ & $\begin{array}{l}-0.015 \\
(0.093)\end{array}$ & $\begin{array}{c}-0.383 * * * \\
(0.098)\end{array}$ & $\begin{array}{c}-0.195 * * \\
(0.082)\end{array}$ & $\begin{array}{c}-0.279 * * * \\
(0.077)\end{array}$ \\
\hline OBC & $\begin{array}{l}-0.021 \\
(0.086)\end{array}$ & $\begin{array}{c}-0.285^{* * * *} \\
(0.070)\end{array}$ & $\begin{array}{l}-0.037 \\
(0.092)\end{array}$ & $\begin{array}{l}-0.001 \\
(0.069)\end{array}$ & $\begin{array}{c}-0.268 * * * \\
(0.085)\end{array}$ & $\begin{array}{c}-0.006 \\
(0.070)\end{array}$ & $\begin{array}{c}-0.184 * \\
(0.093)\end{array}$ \\
\hline Constant & $\begin{array}{c}0.400 \\
(0.623)\end{array}$ & $\begin{array}{c}0.625 \\
(0.466)\end{array}$ & $\begin{array}{l}-0.063 \\
(0.505)\end{array}$ & $\begin{array}{c}0.747 \\
(0.625)\end{array}$ & $\begin{array}{c}0.498 \\
(0.624)\end{array}$ & $\begin{array}{c}0.326 \\
(0.536)\end{array}$ & $\begin{array}{c}0.455 \\
(0.718)\end{array}$ \\
\hline $\begin{array}{l}\text { Observations } \\
\text { R-squared }\end{array}$ & $\begin{array}{l}1,875 \\
0.071\end{array}$ & $\begin{array}{l}1,882 \\
0.064\end{array}$ & $\begin{array}{l}1,898 \\
0.053\end{array}$ & $\begin{array}{l}1,895 \\
0.047\end{array}$ & $\begin{array}{l}1,902 \\
0.058\end{array}$ & $\begin{array}{l}1,825 \\
0.058\end{array}$ & $\begin{array}{l}1,864 \\
0.069\end{array}$ \\
\hline
\end{tabular}

Note: The regressions include session fixed effects. Standard errors in parentheses are clustered at the session level. $* * * \mathrm{p}<0.01, * * \mathrm{p}<0.05, * \mathrm{p}<0.10$. Controls include full-set of RHS variables included in Columns 1-7 in Table 4.

Source: Authors' calculations. 